\title{
The role of dissolved organic matter bioavailability in promoting phytoplankton blooms in Florida Bay
}

\author{
Joseph N. Boyer*, Susan K. Dailey, Patrick J. Gibson, Matthew T. Rogers \& \\ Danielle Mir-Gonzalez \\ Southeast Environmental Research Center, OE-178, Florida International University, Miami, FL 33199, USA \\ (*Author for correspondence: Tel.: +1-305-348-4076; Fax:+1-305-348-4096; E-mail: boyerj@fiu.edu)
}

Key words: dissolved organic matter, cyanobacteria, microbial ecology, nutrients, phytoplankton, phosphorus, estuary

\begin{abstract}
The clear, shallow, oligotrophic waters of Florida Bay are characterized by low phytoplankton biomass, yet periodic cyanobacteria and diatom blooms do occur. We hypothesized that allochthonous dissolved organic matter (DOM) was providing a subsidy to the system in the form of bound nutrients. Water from four bay sites was incubated under natural light and dark conditions with enrichments of either DOM $(>1 \mathrm{kD}, 2 \times \mathrm{DOM})$ or inorganic nutrients $(\mathrm{N}+\mathrm{P})$. Samples were analyzed for bacterial numbers, bacterial production, phytoplankton biomass, phytoplankton community structure, and production, nutrients, and alkaline phosphatase (AP) activity. The influence of $2 \times \mathrm{DOM}$ enrichment on phytoplankton biomass developed slowly during the incubations and was relatively small compared to nutrient additions. Inorganic nutrient additions resulted in an ephemeral bloom characterized initially as cyanobacterial and brown algae but which changed to dinoflagellate and/or brown algae by day six. The DIN:TP ratio decreased 10-fold in the $\mathrm{N}+\mathrm{P}$ treatments as the system progressed towards $\mathrm{N}$ limitation. This ratio did not change significantly for $2 \times$ DOM treatments. In addition, these experiments indicated that both autotrophic and heterotrophic microbial populations in Florida Bay may fluctuate in their limitation by organic and inorganic nutrient availability. Both $\mathrm{N}+\mathrm{P}$ and $2 \times \mathrm{DOM}$ enrichments revealed significant and positive response in bioavailability of dissolved organic carbon (BDOC). Potential BDOC ranged from 1.1 to $35.5 \%$, with the most labile forms occurring in Whipray Basin. BDOC at all sites was stimulated by the $2 \times$ DOM addition. Except for Duck Key, BDOC at all sites was also stimulated by the addition of N + P. BDOC was lower in the dry season than in the wet season $(5.56 \%$ vs. $16.86 \%)$. This may be explained by the distinct chemical characteristics of the DOM produced at different times of year. Thus, both the heterotrophic and autotrophic microbial communities in Florida Bay are modulated by bioavailability of DOM. This has ramifications for the fate of DOM from the Everglades inputs, implicating DOM bioavailability as a contributing factor in regulating the onset, persistence, and composition of phytoplankton blooms.
\end{abstract}

\section{Introduction}

Florida Bay is a wedge-shaped lagoonal estuary separated from the Straits of Florida by the Florida Keys (Fig. 1). Carbonate mud banks compartmentalize Florida Bay into a network of shallow basins, restricting circulation amongst them. Tidal advection from the Gulf of Mexico is quickly attenuated by the western mud banks leaving most of central and northeastern Florida
Bay unaffected (Turney \& Perkins, 1972; Holmquist et al., 1989). Freshwater inputs to Florida Bay are mostly from rainfall and flow from the southern Everglades through the Taylor Slough basin. Taylor Slough is significantly affected by water management activities, which can subsequently influence salinities in the eastern Bay (Boyer \& Jones, 1999). Another potentially important source of freshwater to the Bay is overland flow along the north-central terrestrial 


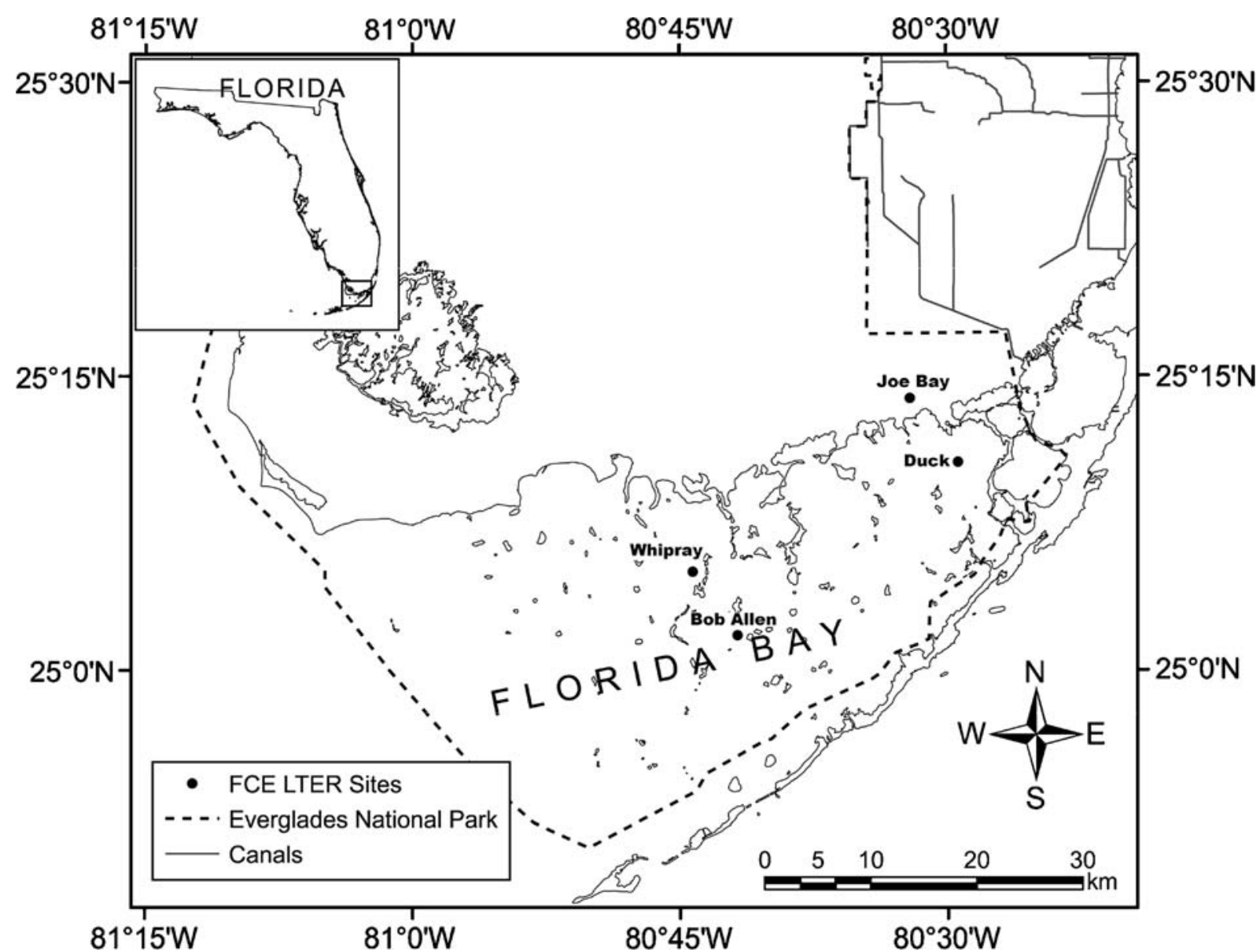

Figure 1. The four sites in Florida Bay which were selected for BDOC experiments: Joe Bay, Duck Key, Whipray Basin, and Bob Allen Key. Each site is representative of different water quality and hydrology conditions.

boundary, the Buttonwood Embankment, which is high in DOM (Fig. 2, Boyer, 2005).

Phytoplankton biomass in eastern Florida Bay is strongly limited by $\mathrm{P}$ (Fourqurean et al., 1993; Phlips \& Badylak, 1996; Boyer et al., 1997; Lavrentyev et al., 1998), however other resources (e.g. light, $\mathrm{N}, \mathrm{Si}$ ) have been shown to partially control productivity in the central and western bay (Lavrentyev et al., 1998; Brand, 1999). Dissolved inorganic P concentrations (measured as soluble reactive $\mathrm{P}, \mathrm{SRP})$ are extremely low $(\sim 0.03 \mu \mathrm{M}$; eastern bay), while dissolved inorganic nitrogen concentrations (DIN; mostly ammonium) can reach $100 \mu \mathrm{M}$ in the central bay (Boyer et al., 1997, 1999).

The occurrence of extensive phytoplankton blooms in central Florida Bay has precipitated a significant amount of public, political, and scientific concern. Interestingly, these blooms are often dominated by cyanobacteria (Phlips \& Badylak, 1996; Steidinger et al., 1996; Phlips et al., 1999). The ability to fix atmospheric $\mathrm{N}_{2}$ may give cyanobacteria a selective advantage in areas of both low $\mathrm{N}$ concentrations as well as low dissolved $\mathrm{N}: \mathrm{P}$ ratios (Phlips et al., 1989). In the ocean gyres where $\mathrm{N}$ concentrations are very low, $\mathrm{N}_{2}$ fixation by cyanobacteria may provide a significant source of $\mathrm{N}$ to the system. In freshwater lakes and rivers, where $\mathrm{P}$ concentrations may be high due to external loading, $\mathrm{N}_{2}$ fixation fuels the massive floating mats of cyanobacteria. Neither of the above conditions applies to Florida Bay, necessitating a new conceptual model to explain the prevalence of cyanobacteria in the system. 


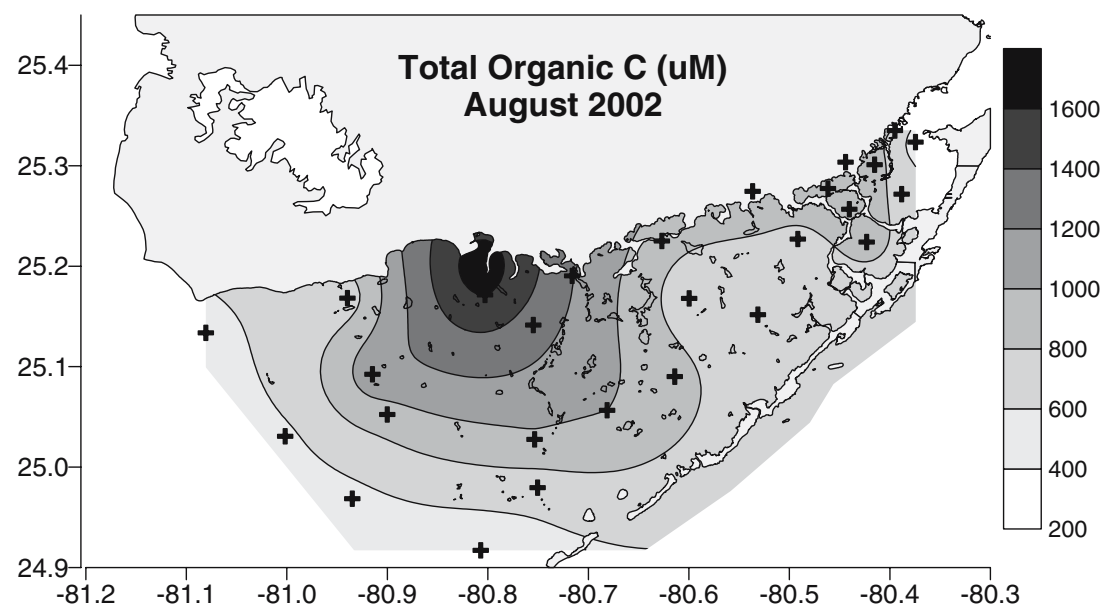

Figure 2. Distribution of total organic carbon $(\mu \mathrm{M})$ across Florida Bay in August 2002, showing usual concentration of high levels in north-central bay (from Boyer, 2005).

The connection between phytoplankton productivity and nutrient loading inputs to estuaries has been repeatedly demonstrated (Boynton et al., 1982). However, data from eastern Florida Bay show that while nutrient loading increases with flow through the Taylor Slough, inflowing nutrient concentrations actually decline (Boyer \& Jones, 1999; Rudnick et al., 1999). This pattern does not follow the typical eutrophication model because the limiting nutrient actually becomes more dilute as the input flows increase. In addition, the concentration of incoming $\mathrm{P}$ is slightly below the ambient concentrations of the bay, meaning that the concentration of $\mathrm{P}$ loading is at or below the kinetic threshold for phytoplankton uptake.

Most nutrient and phytoplankton studies to date have been primarily concerned with the amounts of dissolved inorganic $\mathrm{N}$ and $\mathrm{P}$ as these fractions are directly available for phytoplankton uptake. However, most of the $\mathrm{N}$ and $\mathrm{P}$ in the water column of Florida Bay is present as DOM (Boyer et al., 1997). The question we then ask is how much of the $\mathrm{N}$ and $\mathrm{P}$ in DOM is accessible to the phytoplankton? Specific components of DOM, such as urea, may be taken up directly by some phytoplankton (Waser et al., 1998; Lewitus et al., 2000; Glibert et al., 2004), but they are typically minor fractions of the pool. Therefore, the majority of the DOM pool must first be remineralized to the inorganic forms by bacteria prior to phytoplankton uptake.
The bioavailability of DOM depends upon both the chemical structure (Benner et al., 1986; Amon \& Benner, 1996) and the C:N:P ratio of the source material (Tezuka, 1990). Bacterial utilization of DOM, and subsequent grazing on these bacteria by protists and microzooplankton (the microbial loop), is an important alternative pathway in many aquatic food webs (Azam et al., 1983). The microbial loop may also play a significant role in nutrient remineralization when C:N and C:P ratios are low. Conversely, when nutrient concentrations are limiting, bacteria compete with phytoplankton for inorganic nutrients (Caron, 1994). Therefore, the bioavailability of the DOM pool can determine whether the microbial loop is a source or sink for dissolved nutrients in the water column.

Little is known about the microbial loop in Florida Bay. Data on bacterial production, community structure, and grazing activity of heterotrophic nanoflagellates and ciliates are virtually absent. Bugden et al. (1998) measured heterotrophic potential $\left({ }^{14} \mathrm{C}\right.$-glucose uptake) and direct counts of bacteria and found the central Bay to have highest activity and biomass, followed by the western bay. They also found significant correlations between DOC, heterotrophic activity and bacterial counts. Differences in biogeochemical nutrient cycles and processing of DOM appear to influence the productivity of sub-regions of Florida Bay (e.g. the presence vs. lack of phytoplankton blooms; Phlips et al., 1999) and these differences were linked to the structure and activity of the 
microbial food web (Lavrentyev et al., 1998). The little available information reveals that dissolved nutrient concentrations increased during the wet season and towards the river mouths and heterotrophic bacterioplankton growth was less nutrient limited at sites closer to Everglades runoff and during periods of high rain (Cotner et al., 2000).

In Florida Bay, $88 \%$ of the total phosphorus pool (TP) is in the form of dissolved organic phosphorus (DOP; Boyer et al., 1997). This is a result of biological uptake, the extremely low SRP loading concentrations (from uptake within the Everglades) and because of abiotic binding of $\mathrm{PO}_{4}^{3-}$ to carbonate sediments (Kitano et al., 1978). This results in the emergence of DOP as a potentially important $\mathrm{P}$ source, for those organisms which can access it. Alkaline phosphatase (AP) is an inducible ectoenzyme produced in response to low SRP concentrations by bacteria, cyanobacteria, and some algae, which hydrolyzes DOP to $\mathrm{PO}_{4}^{3-}$ (Chrost, 1990). AP activity is usually inversely related to (Smith \& Kalff, 1981) and down-regulated by, high SRP concentrations (Ammerman \& Azam, 1991). We have measured AP activity at 28 sites in Florida Bay for the past 15 years (Boyer, 2005) and found that AP activity is positively correlated with DOC concentrations, not with SRP or algal biomass as expected (Boyer et al., 1997). Both AP activity and DOC concentrations are three times higher in the central bay than the eastern bay. We believe that the microbial community in the eastern Bay is co-limited by $\mathrm{P}$ and $\mathrm{C}$ as it serves no purpose for microorganisms to express AP when there is no substrate present. Unfortunately, neither DOP bioavailability nor its contribution to primary production is known for this ecosystem.

Our understanding of bacterial and algal coupling dynamics and nutrient mineralization is incomplete, largely because no one experiment addresses DOM uptake by both trophic constituents. In addition, the quality/lability of DOM is a function of its chemical characteristics, molecular weight, elemental ratio (C:N:P:other) and age. Stimulation of AP activity and algal biomass as chlorophyll $a$ (CHLA) by the addition of DOM has been demonstrated in estuarine microcosms (Carlsson \& Graneli, 1993). Previous studies have also demonstrated the importance of DOP in phytoplankton metabolism (see review by Cem- bella et al., 1984) but kinetic experiments by Bentzen et al. (1992) showed that the bacterial fraction dominated P uptake (as ATP), while small nanoplankton $(1-12 \mu \mathrm{m})$ obtained some $\mathrm{P}$ and phytoplankton $>12 \mu \mathrm{m}$ took up very little. These results lead us to believe that AP activity is the main pathway by which both bacteria and phytoplankton in Florida Bay obtain $\mathrm{P}$ for growth and reproduction.

In addition to AP activity, DOM bioavailability may also help to explain the prevalence of cyanobacteria over eukaryotic algae in blooms in the central Bay. Cyanobacteria have much higher cellspecific AP production than do eukaryotic algae (Garaudet et al., 1997). This means that when $P$ is limiting, cyanobacteria have an enhanced ability to hydrolyze DOM for the P contained therin. We also proposed that the bioavailability of DOM provides a labile $\mathrm{N}$ source that may be important in promoting bacterial and/or cyanobacterial production. The observation that the cyanobacteria blooms usually begin in the central Bay where episodic DOM inputs occur adds support to this idea. Therefore we propose that spatial patterns in primary production of bacteria and phytoplankton in Florida Bay are a product of dissolved inorganic and dissolved organic nutrient availability and that, under P limited conditions, cyanobacteria are favored over eukaryotic algae by their greater cell-specific production of AP.

We tested these hypotheses in Florida Bay by incubating water samples using a combination four treatments: ambient light incubation, dark incubation, DIN and SRP enrichment, and DOM amendments. From these treatments we expected to quantify (1) the effect of inorganic nutrients vs. DOM on phytoplankton production and community structure; (2) the bacterial contribution to ambient community production; and (3) the effect of bioavailability of ambient and amended DOM on phytoplankton production and community structure.

\section{Methods}

DOM bioavailability experiments

We sampled four sites distributed throughout Florida Bay for routine BDOC experiments 
(Fig. 1). These sites, Joe Bay, Duck Key, Bob Allen Key and Whipray Basin, were representative of different water quality zones existing in the bay (Boyer et al., 1997). All 4 sites have higher median AP activity and CHLA concentration relative to the other 24 sites in Florida Bay (Boyer, 2005). Thus we expected to see the greatest response of microbial activity to increased substrate availability from these sites. We conducted a total of five bioavailability incubation experiments from July 2001 to July 2002. We also collected field and nutrient data from all sites monthly during this period in conjunction with our Coastal Water Quality Monitoring Network (Boyer, 2005). Duplicate samples were collected in pre acid-washed, autoclaved distilled deionized (ADDI) water rinsed, 2.51 polycarbonate bottles. Bottles were rinsed with sample water three times immediately prior to sample collection. Water was collected from a $\sim 10 \mathrm{~cm}$ depth and bottles were kept in the dark and on ice for transport.

Enrichments of dissolved inorganic nutrients $(\mathrm{N}+\mathrm{P}), \mathrm{DOM}$, and a control were applied under both the light and dark conditions. Raw water from each site was filtered through a $0.5 \mathrm{~mm}$ Nitex screen prior to use to remove any large particles or zooplankton. Nutrient treatments were conducted by adding both $\mathrm{NH}_{4} \mathrm{NO}_{3}$ and $\mathrm{KH}_{2} \mathrm{PO}_{4}$ to a final added $\mathrm{N}+\mathrm{P}$ concentration of $10 \mu \mathrm{M}$ and $1 \mu \mathrm{M}$, respectively. DOM additions were conducted by concentrating water using tangential flow fractionation filtration (TFF) with a Millipore Pellican-2 system with a $1 \mathrm{kD}$ pore diameter membrane. Using this method, particles smaller than the membrane pore size are discarded in the wastewater and only particles larger than $1 \mathrm{kD}$ are retained. DOM concentrate was obtained from Taylor Slough (Florida Coastal Everglades (FCE) LTER site TS/Ph 6 or Argyle Henry). During the TFF process we concentrated the DOM to a final concentration 8-12 times the original. We dispensed the DOM concentrate to a final concentration of ca. twice the original $(2 \times \mathrm{DOM})$ to a total volume of 21 . Control bottles were set up same as the treatments, but otherwise left unaltered.

Incubations were conducted in 2.51 polycarbonate bottles. Clear bottles were used for light treatments; dark bottles were wrapped with aluminum foil tape. Bottles were incubated on a floating line in the FIU campus lake in order to expose them to ambient light, temperature, and wave action (mixing).

Sub-samples were collected from the incubation bottles on $0,1,3,5$ or 6 , and 10-day intervals. The sampling procedure consisted of collecting water from the incubation bottles using sterile, amber HDPE bottles for transport. Incubation bottles were homogenized by gentle inversion three times and the transport bottles were rinsed with sample water three times prior to filling.

\section{Nutrient analyses}

Unfiltered water samples were analyzed for total organic carbon (TOC), total nitrogen (TN), total phosphorus (TP), and alkaline phosphatase (AP) activity. TOC was measured by direct injection onto hot platinum catalyst in a Shimadzu TOC5000 after first acidifying to $\mathrm{pH}<2$ and purging with $\mathrm{CO}_{2}$-free air. TN was measured using an ANTEK $7000 \mathrm{~N}$ Nitrogen Analyzer using $\mathrm{O}_{2}$ as carrier gas instead of argon to promote complete recovery of the nitrogen in the water samples (Frankovich \& Jones, 1998). TP was determined using a dry ashing, acid hydrolysis technique (Solorzano \& Sharp, 1980). The AP assay measures the activity of alkaline phosphatase, an enzyme used by microorganisms to mineralize phosphate from organic compounds (Hashimoto et al., 1985). This assay is performed by adding a known concentration of an organic phosphate compound (o-methylfluorescein phosphate) to an unfiltered water sample. AP in the water sample cleaves the phosphate, leaving $o$-methylfluorescein, a highly fluorescent compound. The fluorescence of initial and $2 \mathrm{~h}$ incubations were measured using a Gilford Fluoro IV spectrofluorometer (excitation $=430 \mathrm{~nm}$, emission $=507 \mathrm{~nm}$ ) and subtracted to give AP activity $\left(\mu \mathrm{M} \mathrm{h}^{-1}\right)$.

Filtrates (Whatman GF/F) were analyzed for soluble reactive phosphorus (SRP), nitrate + nitrite $\left(\mathrm{NO}_{\mathrm{x}}^{-}\right)$, nitrite $\left(\mathrm{NO}_{2}^{-}\right)$, ammonium $\left(\mathrm{NH}_{4}^{+}\right)$, and silicate $\left(\mathrm{Si}(\mathrm{OH})_{4}\right)$ by flow injection analysis (Alpkem RFA 300). Filters for CHLA content $\left(\mu \mathrm{g}^{-1}\right)$ were allowed to extract for a minimum of 2 days at $-20^{\circ} \mathrm{C}$ before analysis. Extracts were analyzed using a Gilford Fluoro IV Spectrofluorometer (excitation $=435 \mathrm{~nm}$, emission $=$ $667 \mathrm{~nm}$ ) and compared to a standard curve of pure CHLA (Sigma). 
Some parameters were not measured directly, but were calculated by difference. Nitrate $\left(\mathrm{NO}_{3}^{-}\right)$ was calculated as $\mathrm{NO}_{\mathrm{x}}^{-}-\mathrm{NO}_{2}^{-}$. Dissolved inorganic nitrogen (DIN) was calculated as $\mathrm{NO}_{\mathrm{x}}^{-}+\mathrm{NH}_{4}^{+}$. Total organic nitrogen (TON) was defined as $\mathrm{TN}-\mathrm{DIN}$. Concentrations for all of these water quality variables are reported in $\mu \mathrm{M}$, except where noted.

\section{Microbial analyses}

Pulse amplitude modulated fluorometry (Walz PhytoPAM) was used to quantify the phytoplankton community structure and photosynthetic quantum yield (QY) or maximum efficiency of photosystem II (PSII). QY was expressed as the ratio of variable fluorescence to maximum fluorescence $\left(F_{\mathrm{v}} / F_{\mathrm{m}}\right)$. Sample water was allowed to sit at $4{ }^{\circ} \mathrm{C}$ overnight prior to analysis to ensure complete reduction of PSII. A $3 \mathrm{ml}$ aliquot was first run in the PAM fluorometer to determine the range of fluorescence for the individual sample and gain was adjusted accordingly. Next a $3 \mathrm{ml}$ aliquot was filtered though a $0.2 \mu \mathrm{m}$ filter and used to determine the background fluorescence at each site. Finally, $3 \mathrm{ml}$ of whole water was analyzed again for total CHLA, CHLA concentrations for cyanobacteria fraction $\left(\mathrm{CHLA}_{\mathrm{CY}}\right)$, green $\left(\mathrm{CHLA}_{\mathrm{GR}}\right.$, which also included dinoflagellates), and brown algal groups

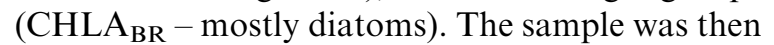
subjected to an actinic light saturation pulse regime in order to measure QY.

Bacterial counts (BACT) were determined by epifluorescence microscopy using DAPI staining technique (Coleman, 1980; Porter \& Feig, 1980). Sample water was collected and fixed with buffered formalin solution to a final concentration of $2 \%$. Samples were incubated at a final concentration of $25 \mu \mathrm{g} \mathrm{ml}^{-1}$ DAPI (Molecular probes ${ }^{\odot}$ ) in a dark filtration tower for $20 \mathrm{~min}$ prior to filtration onto a $0.2 \mu \mathrm{m}$ black polycarbonate filter. The filter was mounted onto a slide with low fluorescent immersion oil and examined under a $100 \mathrm{~W} \mathrm{Hg}$ bulb by counting 10 sampling fields of a known size per slide, with a minimum of 300 cells per slide counted. A final value of cells ml ${ }^{-1}$ was obtained with a formula using the sample volume counted and the percentage of effective filter area counted.

Bacteria production (BP) was determined using ${ }^{3} \mathrm{H}$-thymidine incorporation incubations (Bell,
1993). Triplicates of each sample were analyzed along with a $4 \%$ formalin blank sample for specific activity determination. Disintegrations per minute (dpm) from the liquid scintillation counter were converted using then following equation:

$$
\begin{aligned}
& \mu \mathrm{gCl} \mathrm{Cl}^{-1} \mathrm{~h}^{-1}=\left(\text { moles thymidine } \mathrm{l}^{-1} \mathrm{~h}^{-1}\right) \\
& \text { * }\left(\text { cells mole }^{-1}\right) *\left(\text { carbon cell }^{-1}\right)
\end{aligned}
$$

where picomoles of thymidine incorporated were calculated through using the actual activity of the ${ }^{3} \mathrm{H}$ thymidine $(\mathrm{dpm})$ versus the bacterial activity from live-killed (dpm).

Cells mole ${ }^{-1}$ was determined by multiplying the thymidine conversion factor of $2 \times 10^{18}$ cells mole ${ }^{-1}$ by the moles of thymidine $1^{-1} \mathrm{~h}^{-1}$. For the amount of carbon per cell we used the $20 \mathrm{fg}$ conversion rate used in coastal waters. Our observations of water from these Florida Bay sites over the past two years have shown bacteria numbers that are consistently lower than those found in estuaries or other coastal systems but can be highly variable across sampling months. Thus we used a mid-value conversion factor to multiply the number of cells by to estimate the change in $\mathrm{C}$ content (Bell, 1993).

\section{DOM fluorescence analyses}

Fluorescence emission and synchronous fluorescence were measured using a Perkin Elmer LS50B spectrofluorometer with a $150 \mathrm{~W}$ Xenon light source to analyse $3 \mathrm{ml}$ aliquots of sample. $20 \mathrm{ml}$ of water was filtered though a Whatman GF/F prior to fluorescence analyses with all samples processed within 7 days of collection. Samples were first run for UV-visible data that were used to correct the data we collected for maximum fluorescence intensity $\left(F_{\max }\right)$, maximum wavelength of fluorescence $\left(\lambda_{\max }\right)$, fluorescence index $\left(\mathrm{FI}\right.$ as $\left.\mathrm{f}_{450 / 500}\right)$, and relative percent of Peak 1 (at $285 \mathrm{~nm}$, Jaffe et al., 2003).

\section{Statistical analyses}

Data from incubation experiments were fitted to a one-phase exponential decay equation where $X$ is time, and $Y$ is DOC concentration. 


$$
Y=\text { Span } \mathrm{e}^{-K * t}+\text { Plateau }
$$

$Y$ starts out equal to Span + Plateau and decreases to Plateau at a rate of $K\left(\mathrm{~d}^{-1}\right)$. The percent of bioavailable DOC (BDOC) in the pool was calculated as Span/(Plateau + Span $) * 100$. If the equation could not be resolved because of variability, the linear difference between beginning and end was used.

Variables were tested between groups using the nonparametric Wilcoxon Ranked Sign test (comparable to the $t$-test) and among groups by the Kruskal-Wallis test (comparable to ANOVA) with significance set at $p \leq 0.05$. Groups that were significantly different were tested by Mann-Whitney $U$ test in order to say how the groups differed by comparing medians of all paired cluster groups among all physical site parameters and/ or taxa at a level of $p<0.05$ (2-tailed test). In addition, variables by station were visualized using box-andwhiskers plots, where the center horizontal line of the box is the median, the top and bottom of the box are the 25th and 75 th percentiles (quartiles), and the ends of the whiskers are the 5th and 95th percentiles. Outliers were suppressed to reduce figure compression.

\section{Results and discussion}

\section{Site characteristics}

The sites we chose for this study were selected as being representative of four different zones of Florida Bay. Joe Bay receives seasonally driven, freshwater inputs from fringing mangrove forest. Duck Key is located in shallow estuarine lagoonal area of Florida Bay, which receives minimal tidal energy and is vegetated with sparse seagrass. The Bob Allen site is influenced most by the Atlantic Ocean mixing and is considered the most "oceanic" site. Whipray Basin is hydraulically isolated from the rest of the Bay and only receives episodic terrestrial runoff. It is the shallowest area of the Bay and experiences frequent hypersalinity events.

We hypothesized that difference in physical hydrography would result in dissimilarity of DOM source; ergo, its bioavailability and effect on the microbial loop. Other factors affecting phyto-
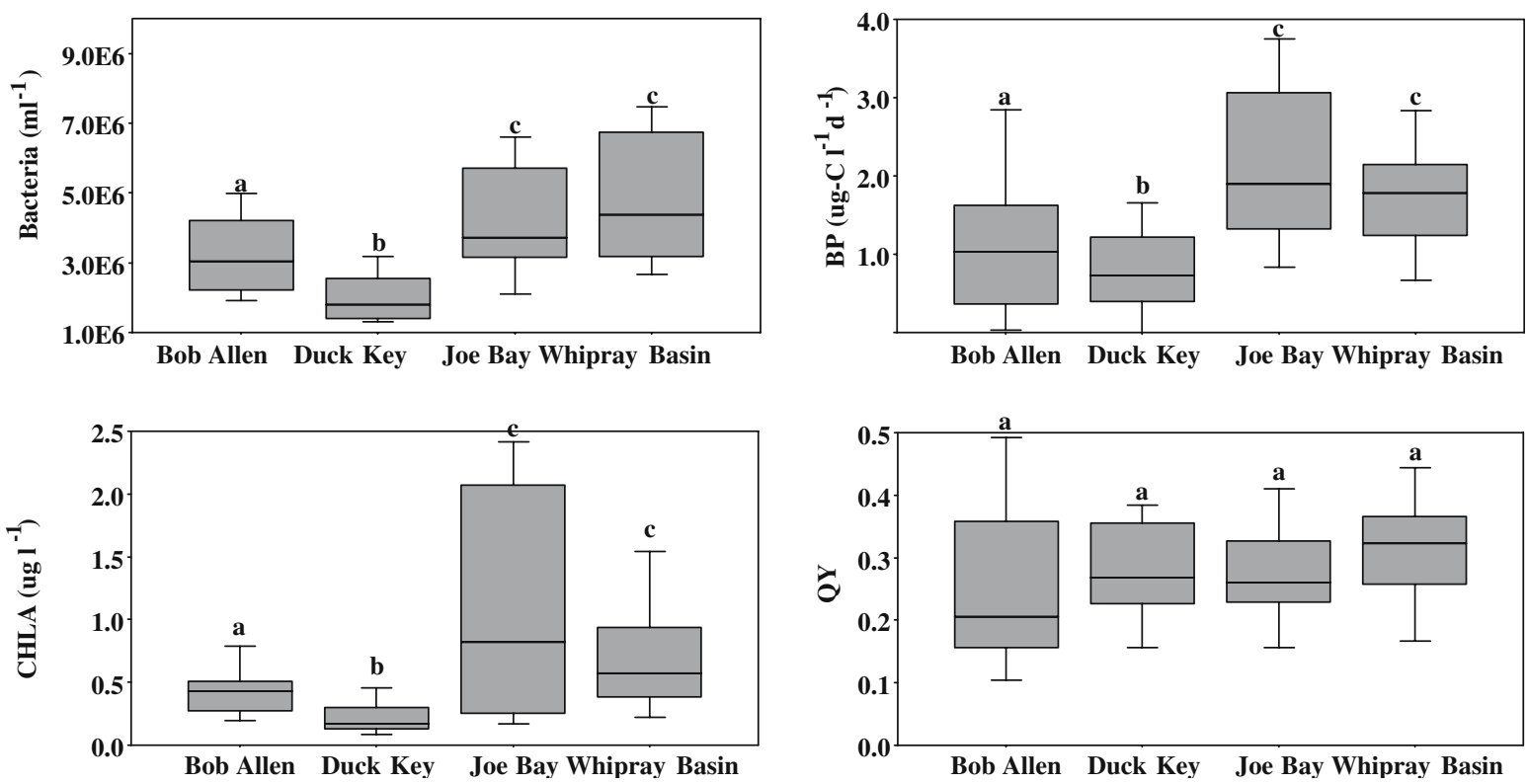

Figure 3. Box and whisker plots of bacterial counts (BACT in $\mathrm{ml}^{-1}$ ), bacterial production (BP as $\mu \mathrm{g}-\mathrm{C} \mathrm{l}^{-1} \mathrm{~d}^{-1}$ ), chlorophyll $a$ (CHLA in $\mu \mathrm{g}^{-1}$ ), and phytoplankton quantum yield (QY). The center horizontal line of the box is the median of the data, the top and bottom of the box are the 25th and 75th percentiles (quartiles), and the ends of the whiskers are the 5th and 95th percentiles. Outliers were suppressed to reduce figure compression. Statistical differences among sites are shown as having different letter labels. 

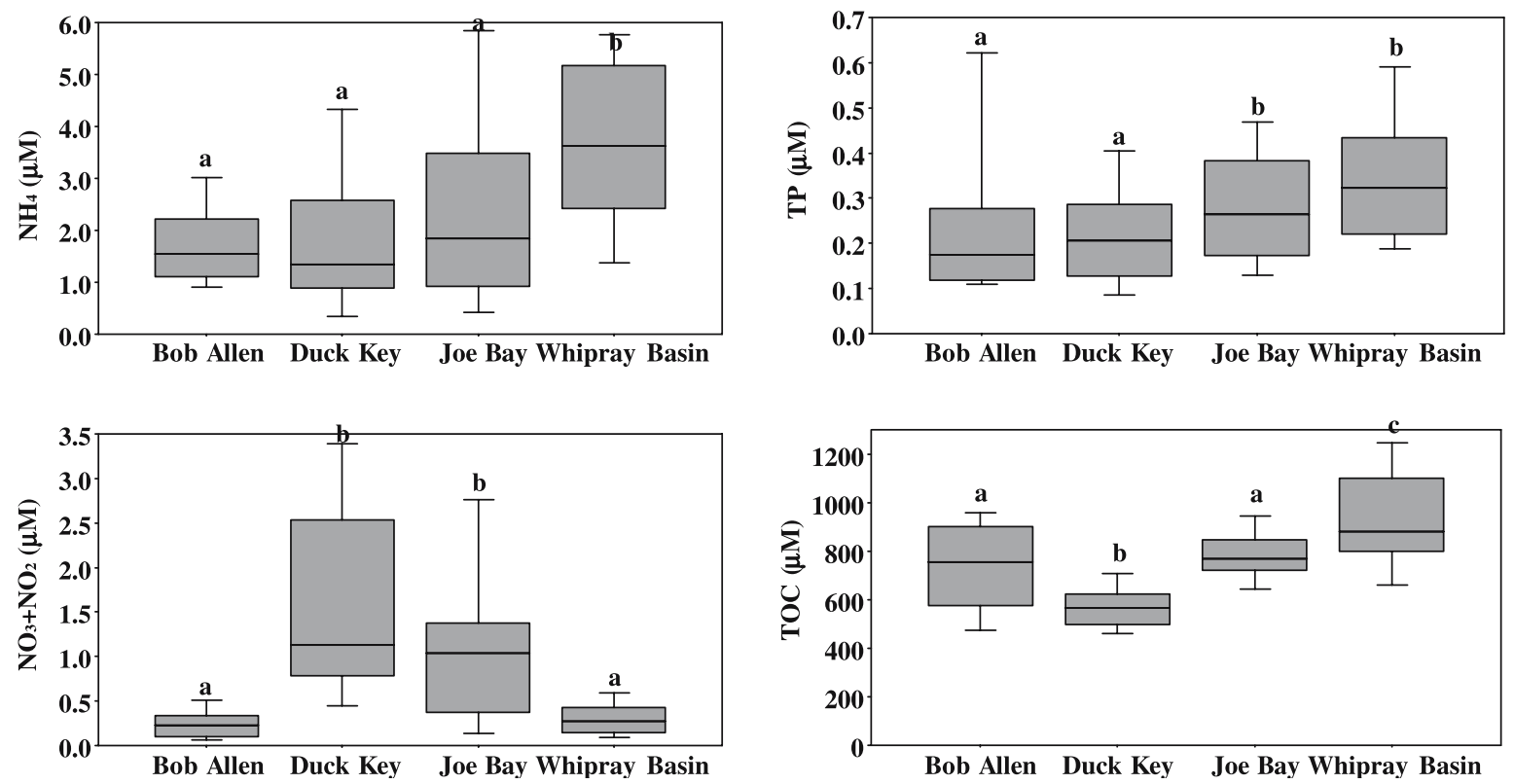

Figure 4. Box and whisker plots of $\mathrm{NH}_{4}^{+}(\mu \mathrm{M}), \mathrm{TP}(\mu \mathrm{M}), \mathrm{NO}_{\mathrm{x}}^{-}(\mu \mathrm{M})$, and TOC $(\mu \mathrm{M})$ showing similarity in distribution of $\mathrm{NH}_{4}^{+}$and TP and inverse relationship between $\mathrm{NO}_{3}^{-}+\mathrm{NO}_{2}^{-}$and TOC.
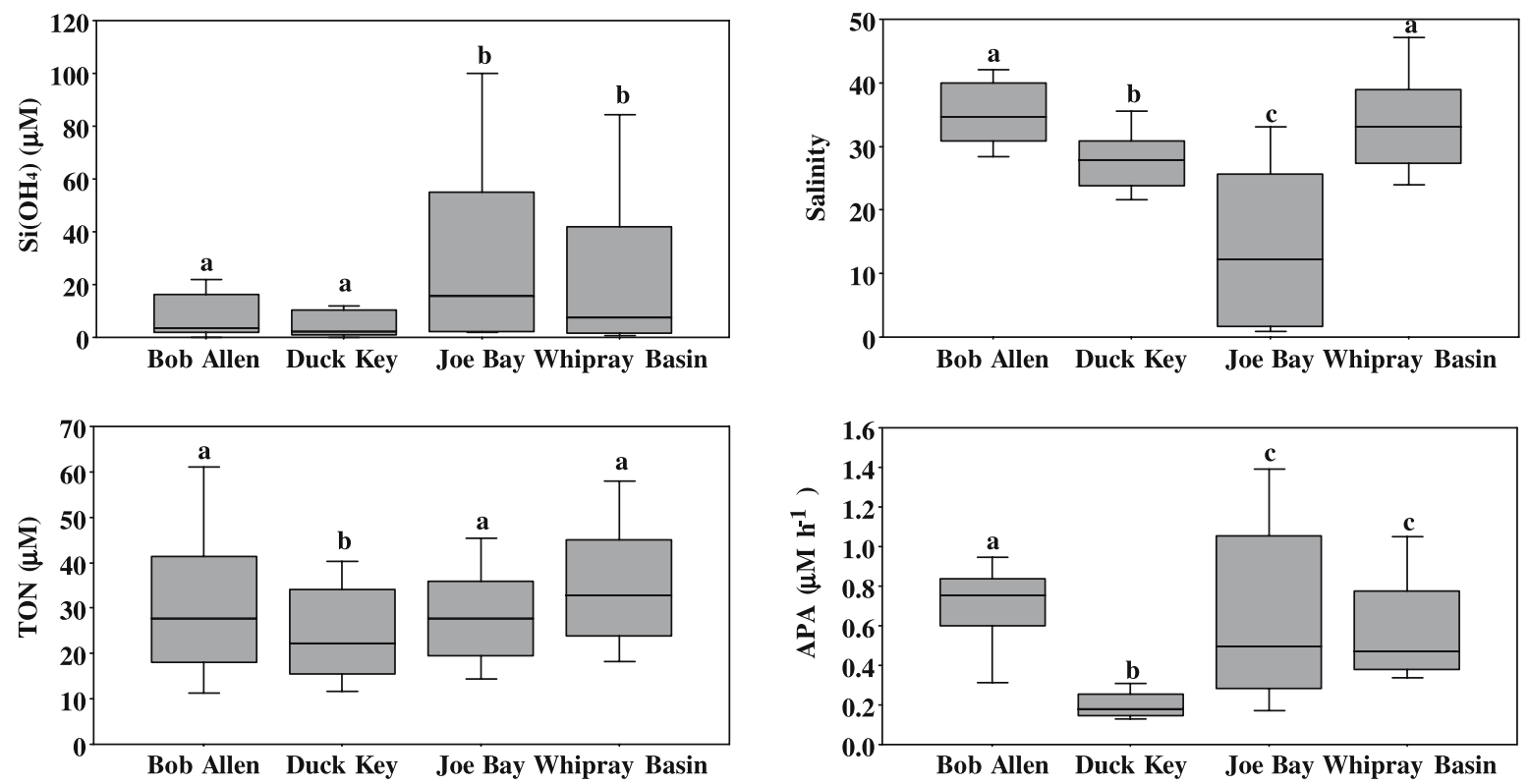

Figure 5. Box and whisker plots of $\mathrm{Si}(\mathrm{OH})_{4}(\mu \mathrm{M})$, salinity, TON $(\mu \mathrm{M})$, and AP activity $\left(\mu \mathrm{M} \mathrm{h}^{-1}\right)$.

plankton and bacteria are the concentration and relative proportion of different nutrient species in the total pool. There were significant differences in all measured variables among sites, except for TON and QY (Figs. 3-6). Joe Bay exhibited lowest salinity, FI, and Peak1 but was high in BACT,
BP, TP, CHLA, AP activity, TOC, $\mathrm{Si}(\mathrm{OH})_{4}, \lambda_{\max }$, and $F_{\max }$. The terrestrial DOM subsidy (high TOC, $\lambda_{\max }$, and $F_{\max }$ with low FI) increased organic P levels (only $4 \%$ of TP is $\mathrm{PO}_{4}^{3-}$, Boyer et al., 1997) along with a corresponding increase in bacterial biomass and production as 

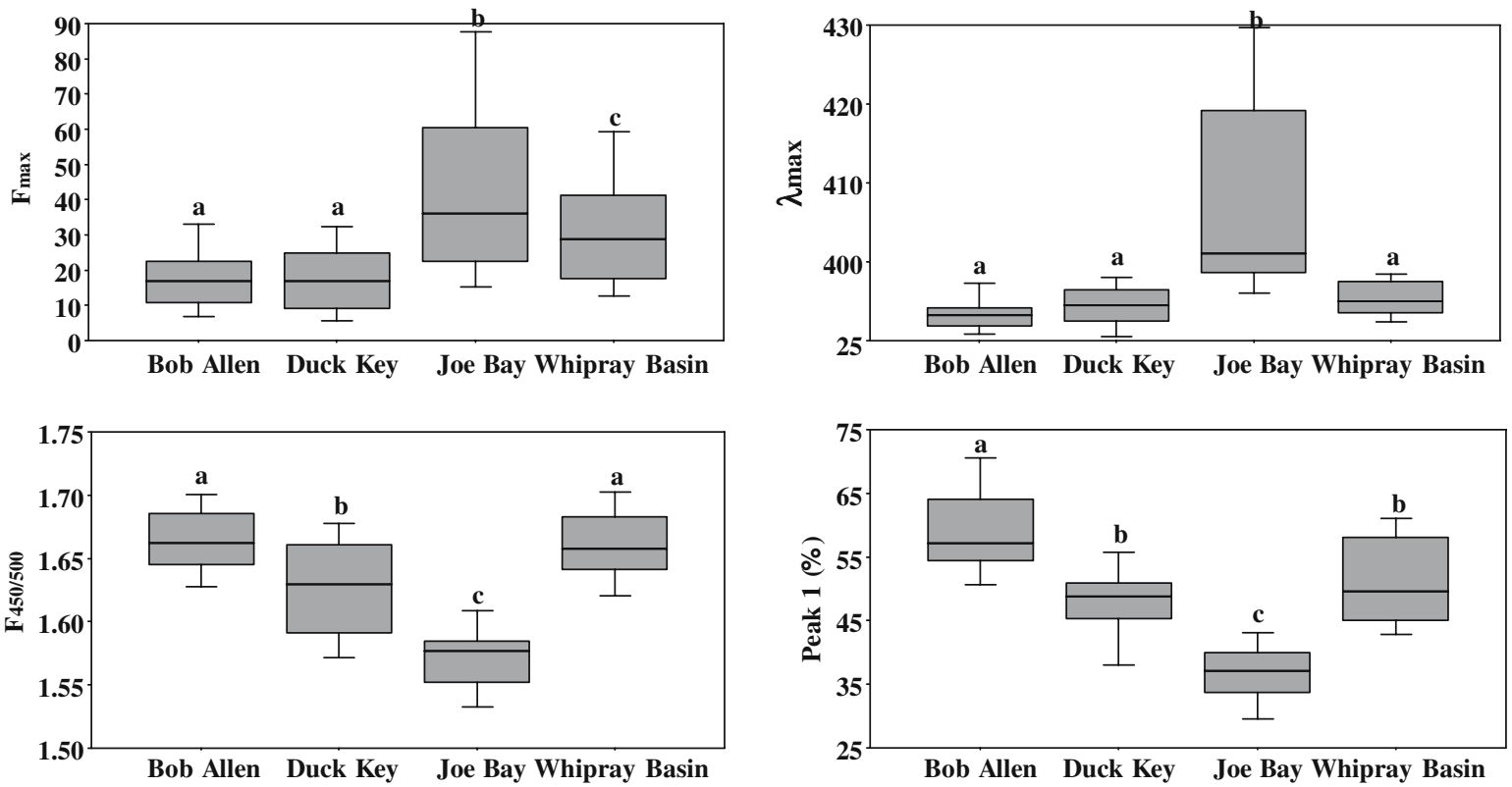

Figure 6. Box and whisker plots of $F_{\max }(\mathrm{QSU}), \lambda_{\max }(\mathrm{nm}), \mathrm{FI}\left(\mathrm{f}_{450 / 500}\right)$, and Peak1 (\%) showing similarity in distribution of $F_{\max }$ and $\lambda_{\max }$ and inverse relationship between these variable and $\mathrm{f}_{450 / 500}$ and Peak 1 .

well as phytoplankton biomass. The fluorescence characterization of DOM (Fig. 6) showed very clearly the inverse relationship between terrestrial DOM (high $F_{\max }$ and $\lambda_{\max }$ ) and those sites having significant microbial and/or seagrass DOM (high FI and Peak1).

Duck Key had low levels of BACT, BP, TP, AP activity, CHLA, TOC, $\mathrm{Si}(\mathrm{OH})_{4}$ and $F_{\max }$ (Figs 36) but was highest in $\mathrm{NO}_{\mathrm{x}}^{-}$. This area achieves the greatest extent and duration of $\mathrm{P}$ limitation conditions seen in the Bay, which results in a buildup of excess $\mathrm{NO}_{\mathrm{x}}^{-}$and low biological biomass and activity. Bob Allen was very low in $\mathrm{NO}_{\mathrm{x}}^{-}, \mathrm{TP}, \lambda_{\max }$, and $F_{\max }$ but high in AP activity, salinity, FI and Peak1. We believe the area around Bob Allen is subsidized by seagrass DOM production (Jaffé pers. comm.) which helps explain the high AP activity, FI, and Peak1 (protein). Whipray Basin was low in $\mathrm{NO}_{\mathrm{x}}^{-}$, but high in BACT, $\mathrm{NH}_{4}^{+}, \mathrm{TP}$, TOC, salinity, and FI. The high levels of these variables indicate a relatively closed system driven by remineralization and benthic flux.

\section{$N+P$ vs. DOM stimulation of autotrophic community (light incubations)}

In this part of the experiment we hypothesized that $\mathrm{N}+\mathrm{P}$ additions would have the greatest effect on primary production and phytoplankton community structure at those sites which had high DOM and low nutrient concentrations - Joe Bay and Whipray Basin. This hypothesis was clearly validated as BACT, BP, CHLA, CHLA GR $_{\text {, and }}$ $\mathrm{CHLA}_{\mathrm{BR}}$ were all significantly higher after ten days of incubation, relative to control (Table 1). Interestingly, nutrient additions did not stimulate

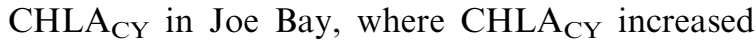
after 3 days but then declined by the end of the incubation. In addition to those sites, we found that BACT, BP, CHLA, CHLA ${ }_{\mathrm{GR}}$, and $\mathrm{CHLA}_{\mathrm{BR}}$ at both Duck Key and Bob Allen were also stimulated by $\mathrm{N}+\mathrm{P}$ additions. CHLA $_{\mathrm{CY}}$ was stimulated by $\mathrm{N}+\mathrm{P}$ additions at Duck Key but not Bob Allen. AP activity was strongly inhibited by $\mathrm{N}+\mathrm{P}$ additions as expected.

We saw no measurable difference in QY across treatments or sites. This was due in part to the very low levels of CHLA present, which were at or near the limits of detection for the assay. The only changes we observed in DOM fluorescence variables was an increase in Peak1 (protein/polyphenolic) at Duck Key and Whipray Basin over time, but it was not statistically significant. This implies that a qualitative change in DOM occurred at these sites as a result of increased phytoplankton production. 
Table 1. Matrix of measured variable response to treatment relative to control. Direction of response is positive or negative with statistical significance set at $p<0.05$

\begin{tabular}{|c|c|c|c|c|c|c|c|c|c|c|c|c|c|}
\hline Condition & Site & Treatment & BACT & $\mathrm{BP}$ & APA & CHLA & $\mathrm{CHLA}_{\mathrm{CY}}$ & $\mathrm{CHLA}_{\mathrm{GR}}$ & $\mathrm{CHLA}_{\mathrm{BR}}$ & $\lambda_{\max }$ & $F_{\max }$ & FI Peak1 I & $\mathrm{BDOC}$ \\
\hline \multirow[t]{8}{*}{ Light } & Duck Key & DOM & + & ++ & ++ & & ++ & & + & & & & \\
\hline & & $\mathrm{N}+\mathrm{P}$ & ++ & +++ & -- & +++ & +++ & +++ & +++ & & & & \\
\hline & Joe Bay & DOM & + & ++ & & & + & & + & & & & \\
\hline & & $\mathrm{N}+\mathrm{P}$ & +++ & +++ & & +++ & & +++ & +++ & & & & \\
\hline & Whipray Basin & DOM & ++ & + & ++ & ++ & + & & ++ & & & & \\
\hline & & $\mathrm{N}+\mathrm{P}$ & ++ & +++ & - & ++ & + & ++ & +++ & & & & \\
\hline & Bob Allen & DOM & ++ & + & ++ & ++ & + & & ++ & & & & \\
\hline & & $\mathrm{N}+\mathrm{P}$ & +++ & +++ & - & ++ & & + & + & & & & \\
\hline \multirow[t]{8}{*}{ Dark } & Duck Key & DOM & + & + & + & & & & & - & - & ++ & + \\
\hline & & $\mathrm{N}+\mathrm{P}$ & & ++ & -- & & & & & - & - & $-\quad-$ & - \\
\hline & Joe Bay & DOM & + & + & + & & & & & - & - & + & + \\
\hline & & $\mathrm{N}+\mathrm{P}$ & & & -- & & & & & & & +- & + \\
\hline & Whipray Basin & DOM & + & + & & & & & & + & & - & ++ \\
\hline & & $\mathrm{N}+\mathrm{P}$ & & ++ & -- & & & & & & & & + \\
\hline & Bob Allen & DOM & + & + & + & & & & & - & - & ++ & ++ \\
\hline & & $\mathrm{N}+\mathrm{P}$ & & ++ & -- & & & & & & & +- & + \\
\hline
\end{tabular}

The number of + or - was related to the magnitude of response ( + was up to a doubling in response, ++ was up to a tripling in response, etc.).

The second part of the light experiment assessed the effect of a doubling of DOM concentration on the phytoplankton community. Because the added DOM was isolated from an upstream Taylor Slough marsh/mangrove site, the net effect was to simulate the potential impact of terrestrial DOM loading to these sites. Contrary to $\mathrm{N}+\mathrm{P}$ treatment, we hypothesized that the effect of the $2 \times$ DOM addition would be greatest at those sites having the lowest DOM concentrations, Duck Key and Bob Allen. DOM subsidy did indeed have a significant effect on the microbial community, but results were not exactly as predicted. Not only were BACT and BP at Duck Key and Bob Allen stimulated, but these variables increased at all sites, regardless of DOM concentration (Table 1). The increases were not as high as those produced by $\mathrm{N}+\mathrm{P}$ additions. The $2 \times \mathrm{DOM}$ subsidy did not enhance CHLA levels at Duck Key or Joe Bay but did affect CHLA at Bob Allen and Whipray Basin, however this occurred later in the incubation (day 10). The $2 \times \mathrm{DOM}$ addition significantly altered the phytoplankton community as well; all sites showed increased $\mathrm{CHLA}_{\mathrm{CY}}$ and $\mathrm{CHLA}_{\mathrm{BR}}$; no increase was noted in $\mathrm{CHLA}_{\mathrm{GR}}$.

One of the most significant effects of $2 \times$ DOM addition was the large stimulation in AP activity at all sites but Joe Bay. This implies that AP activity was induced by addition of organic substrate, not just by decline in inorganic P. Nausch \& Nausch (2004) have shown that AP is another method by which cells can access organic $\mathrm{C}$ along with $\mathrm{P}$. Confounding this result is the fact that the added DOM was from a different source (freshwater marsh) and therefore might be of different quality than that found in the Bay. This might help explain why $2 \times$ DOM stimulated the phytoplankton community in Whipray Basin, an area of high DOM. We are wary about using the fluorescence information as new organic $\mathrm{C}$ was produced during the light incubations, which might confound the interpretation.

The results of the light experiments show that the bacterial community responded to $2 \times \mathrm{DOM}$ addition in a similar manner to $\mathrm{N}+\mathrm{P}$ addition, but at a lower response level. The phytoplankton community responded in a differential manner. Cyanobacterial biomass was stimulated at all sites with DOM additions, while $\mathrm{N}+\mathrm{P}$ addition stimulated CHLA $_{\mathrm{CY}}$ only Duck Key and Whipray Basin. Both $\mathrm{N}+\mathrm{P}$ and $2 \times \mathrm{DOM}$ additions increased diatom biomass but for different reasons: $\mathrm{N}+\mathrm{P}$ were taken up directly by the cells while DOM required the intermediate step of AP 
induction before the $\mathrm{P}$ was available. Apparently, diatoms and cyanobacteria in Florida Bay are capable of producing AP whereas the green algae are not.

\section{$N+P$ vs. DOM stimulation of heterotrophic microbial community (dark incubations)}

Under dark conditions, $\mathrm{N}+\mathrm{P}$ addition did not have any effect on BACT but did increase BP at all but Whipray Basin (Table 1). In contrast, $2 \times$ DOM additions stimulated both BACT and BP at all sites. We did not expect to see significant increases in BP at the high DOM sites, Joe Bay and Whipray Basin, but once again, the terrestrial DOM proved to be more usable than the in situ DOM. Stimulation of BP was greater in $\mathrm{N}+\mathrm{P}$ than $2 \times \mathrm{DOM}$ treatments. These results are consistent with others (Ducklow \& Carlson, 1992; del Giorgio \& Cole, 1998) who have shown that the bacterial response to nutrients is to increase their bacterial growth efficiency (BGE) while the general response to $\mathrm{C}$ is to increase growth and reproduction.

As with the light treatment, a dramatic difference in AP activity between nutrient treatments was observed. $\mathrm{N}+\mathrm{P}$ additions had a strong negative effect on AP activity while $2 \times$ DOM increased AP activity in all but Whipray Basin. It seems that AP activity was already high in Whipray and no further stimulation was possible.

Fluorescent properties $\lambda_{\max }$ and $F_{\max }$ declined with time in DOM addition treatments (except for $\lambda_{\max }$ in Whipray Basin), implying that there was a qualitative shift from terrestrially derived to microbially produced DOM (Table 1). This interpretation was reinforced by the overall increase in FI at the same sites. Peak1 declined at Whipray Basin but increased at the other three sites. A decline in Peak1 is interpreted as a loss of the protein/ polyphenol fraction through photo- or biodegradation (Scully et al., 2004). We expected to see declines in Peak1 across all sites as the more labile proteins were consumed, but this was not the case.

$\mathrm{N}+\mathrm{P}$ additions had a negative effect on $\lambda_{\max }$ and $F_{\max }$ only at Duck Key. This implied that conversion of high molecular weight DOM by bacterial activity was significant only at this site. Oddly, FI also declined at Duck Key but increased at Joe Bay and Bob Allen as the microbial contri- bution to the DOM pool became more pronounced. Peak1 decreased at all but Whipray Basin, indicating microbial use of these components.

\section{Bioavailability of dissolved organic carbon (BDOC)}

We used degradation of DOC as a proxy for overall breakdown of DOM. Batch incubations, such as those employed in this study, typically result in a declining loss of labile DOC where the less reactive fraction becomes a larger component of the total pool over time. In many cases a power function is used to fit the data in an effort to discriminate among dissimilar pools of DOC having different reactivities (del Georgio \& Davis, 2003). The single phase exponential decay gave us the ability to discriminate between labile and recalcitrant DOC pools without having to assume a constantly decreasing reactivity of a single pool. The single phase exponential decay constant $(K)$, therefore, tells only one part of the story; that of how fast the labile fraction is degraded. The plateau told us how much of the pool was relatively recalcitrant. Plateaus for all sites were high relative to initial levels, meaning that only a small portion of the total DOC pool was degraded. Therefore, it is important that both the Span and Plateau be reported along with $K$, or else DOC decomposition may be overestimated.

The bioavailability of the ambient DOC (Control) was not significantly different across sampling sites (Fig. 7). Ambient BDOC ranged from 2.0$12.9 \%$ with a median of $6.5 \%$ (Table 2). Bioavailability in the control incubations across Florida Bay did not appear have a pattern that is regional in scale. The highest bioavailability and one of the very lowest control bioavailability we observed across the study period occurred at northeastern central study site of Joe Bay (1.73 and 14.06\%). Joe Bay is in the ecotone between the Everglades mainland and Florida Bay and is cloistered behind miles of winding mangrove waterway. It is interesting that BDOC was highest in the western Florida Bay sites and in those sites closest to the mangrove estuary and was lowest in the central Florida Bay further from the freshwater ecotone. This suggests that the amount of BDOC from the marsh and mangrove that is transported to Florida Bay is low. This concept was born out in the 


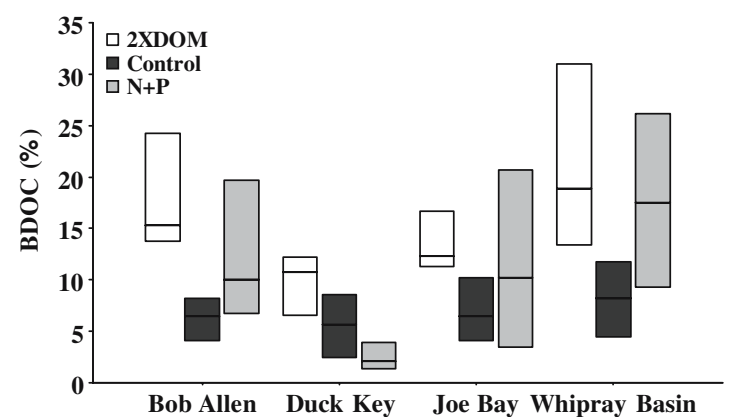

Figure 7. Box and whisker plots of BDOC (\%) by site and treatment showing effects of increased nutrient and DOM on bioavailability.

fluorescence characterizations, where we saw the $2 \times$ DOM amendment was very similar in molecular behavior and fluorescence properties to the ambient DOM in the controls. This provides some validation that indeed our $2 \times$ DOM amendments were similar in structure to the ambient DOM.

There was a significant response in BDOC, relative to Controls, for both the $\mathrm{N}+\mathrm{P}$ and $2 \times$ DOM treatments (Table 1$)$. BDOC at all sites was stimulated by the $2 \times$ DOM addition (Fig. 7). Except for Duck Key, BDOC at all sites was also stimulated by the addition of $\mathrm{N}+\mathrm{P}$. Overall, the $2 \times$ DOM addition provoked greater response than $\operatorname{did} \mathrm{N}+\mathrm{P}$ addition, but it was not always significant. There was no significant difference between the $\mathrm{N}+\mathrm{P}$ and $2 \times \mathrm{DOM}$ treatments at Joe Bay and Whipray Basin sites, although the mean BDOC was higher for the $2 \times \mathrm{DOM}$ treatment. Some of the differences between treatment effects may be due to differences in actual amounts of $\mathrm{N}$ and $\mathrm{P}$ added. In addition to DOC, the $2 \times$ DOM addition added $20 \mu \mathrm{M}$ DON and $0.2 \mu \mathrm{M}$ DOP to the incubation bottles. Therefore, the potential for $\mathrm{N}$ stimulation in the $2 \times \mathrm{DOM}$ treatment was twice that of the $\mathrm{N}+\mathrm{P}$ amendment whereas, the potential $\mathrm{P}$ added as organic matter was only $20 \%$ that of the $\mathrm{N}+\mathrm{P}$ treatment.

We tested bioavailability across time and found that there was a significant difference between the dry and wet seasons. BDOC was lower in the dry season than in the wet season $(5.56 \%$ vs. $16.86 \%)$. This may be explained by the distinct chemical characteristics of the DOM produced at different times of year (Maie et al., 2006). The highest bioavailability that we observed was from the Whipray Basin site with $2 \times$ DOM treatment $(35.5 \%)$. The bioavailability seen at this site in the first wet season experiment was twice what we observed at any other site under any treatment over time and suggests that this site responds more quickly to 'fresh DOC' and more intensely to organic additions.

In our incubation assays, the initial rate of degradation (Table 2) was much slower than from our previous results from freshly leached DOC from mangrove, sawgrass, and seagrass leaves (Sculley et al., 2004). This is consistent with the general idea that increased environmental exposure of DOM results in decreased biological reactivity. The age distribution of the DOM pool may be a significant factor in explaining the variability of measured BDOC estimates. The preponderance

Table 2. Means of single phase exponential decay constants for all BDOC incubations

\begin{tabular}{|c|c|c|c|c|c|}
\hline Treatment & Site & $K\left(\mathrm{~d}^{-1}\right)$ & $\operatorname{Span}(\mu \mathrm{M})$ & Plateau $(\mu \mathrm{M})$ & BDOC $(\%)$ \\
\hline \multirow[t]{4}{*}{ Control } & Duck Key & 0.001 & 50.6 & 554.4 & 6.9 \\
\hline & Joe Bay & 1.480 & 36.1 & 504.6 & 7.0 \\
\hline & Whipray Basin & 0.003 & 77.9 & 724.5 & 9.8 \\
\hline & Bob Allen & 0.005 & 78.7 & 910.0 & 6.7 \\
\hline \multirow[t]{4}{*}{$\mathrm{N}+\mathrm{P}$} & Duck Key & 0.001 & 121.5 & 492.9 & 17.0 \\
\hline & Joe Bay & 1.420 & 10.9 & 499.0 & 2.2 \\
\hline & Whipray Basin & 0.003 & 169.8 & 662.9 & 20.4 \\
\hline & Bob Allen & 0.826 & 259.6 & 741.9 & 26.0 \\
\hline \multirow[t]{4}{*}{ DOM } & Duck Key & 0.088 & 286.3 & 1404.4 & 16.3 \\
\hline & Joe Bay & 0.295 & 183.5 & 1401.5 & 18.7 \\
\hline & Whipray Basin & 0.796 & 213.6 & 1635.0 & 11.7 \\
\hline & Bob Allen & 0.545 & 772.3 & 1264.6 & 36.2 \\
\hline
\end{tabular}


Table 3. Range of bioavailability results of our study compared with those of researchers in estuaries reported across the globe with + standard error when reported or available

\begin{tabular}{llll}
\hline Location of study & BDOC $(\%)$ & Focus of study & Citation \\
\hline Cape Fear River, USA & $9.0 \pm 4.5$ & Total microbial community & Avery et al. (2003) \\
Rio de Janeiro, Brazil & $6.6 \pm 17.4$ & Bacteria only & Fajalla et al. (2002) \\
Baltic Sea & $2-72$ & Heterotrophic community & Stephanaukas (2000) \\
Sacramento-San Joaquin River Delta & $11-15$ & Total microbial community & Sobzjak et al. (2002) \\
Duck Key, Florida Bay USA & $1.3-12.7$ & Total microbial community Dark incubations & This study \\
Joe Bay, Florida Bay, USA & $2.7-25.3$ & Total microbial community Dark incubations & This study \\
Whipray Basin, Florida Bay, USA & $3.1-35.1$ & Total microbial community Dark incubations & This study \\
Bob Allen Keys, Florida Bay USA & $2.5-27.8$ & Total microbial community Dark incubations & This study \\
\hline
\end{tabular}

of older DOM during the dry season may also help explain the seasonal differences in bioavailability (Maie et al., 2006).

BDOC estimates from this study were low but comparable to other studies with low anthropogenic impacts (Table 3). del Giorgio \& Davis (2003) provided an exhaustive review of BDOC results from various ecosystems. They found large differences in initial bioavailability between lakes and marine systems vs. rivers, marshes and estuaries with lakes and marine being 3 - to 5 -fold higher. On an average, $9-10 \%$ of DOC pool was biodegraded after 3 days. Most of these differences were attributed to proportion of algal DOC to the system. In general, autochthonous DOC was more rapidly and more completely utilized than allochthonous DOC.

Our BDOC for the DOM amendment is as high as any reported value in the literature (Table 3). This suggests a feedback loop where higher concentrations of DOC introduced to Florida Bay from the mainland Everglades, either through pulse events such as hurricanes, massive rains, or human altered water events, can lead to higher bioavailability and eventually higher DOC concentrations. Nutrients provided in the form of organic matter stimulated increases in BDOC that were equivalent to inorganic nutrients alone. An increase in DOM loading from the Everglades, especially during the wet season, may therefore produce a response equal to or greater than the response from inorganic nutrient enrichment because it is transporting fresher material to the estuary. This suggests that both inorganic and organic forms of nutrients can be limiting factors for bacteria and phytoplankton populations in the area. Further, it supports the argument that the microbial population of Florida Bay responds to allochthonous carbon inputs to the water column, such as those conditions that may exist in pulsed energy events such floods and hurricanes.

\section{Acknowledgements}

This research was made possible through NOAA Grant \#NA06OP0517. We also acknowledge the support of Florida Coastal Everglades LTER under NSF Grant \#DEB-9901514 for personnel and field support. We would like to thank Emily Kuhnlein and the Microbial Ecology Lab at SERC for their tremendous efforts assisting this research project. This is contribution \#286 of the Southeast Environmental Research Center at Florida International University.

\section{References}

Ammerman, J. W. \& F. Azam, 1991. Bacterial 5'-nucleosidase activity in estuarine and coastal marine waters: characterization of enzyme activity. Limnology and Oceanography 36 : 1427-1436.

Amon, R. M. W. \& R. Benner, 1996. Bacterial utilization of different size classes of dissolved organic matter. Limnology and Oceanography 41: 41-51.

Avery, G. B. Jr., J. D. Willey, R. J. Kieber, G. C. Shank \& R. F. Whitehead, 2003. Flux and bioavailability of Cape Fear River and rainwater dissolved organic carbon to Long Bay, southeastern United States. Global Biogeochemical Cycles 17: 1042 .

Azam, F., T. Fenchel, J. G. Field, A. Meyer-reil \& F. Thingstad, 1983. The ecological role of water-column microbes in the sea. Marine Ecology Progress Series 10: 257-263.

Bell, R. T., 1993. Estimating production of heterotrophic bacterioplankton via incorporation of tritiated thymidine. In 
Kemp, P. F., B. F. Sherr, E. B. Sherr \& J. J. Cole (eds.), Handbook of Methods in Aquatic Microbial Ecology. Lewis Publishers, Boca Raton, Florida, 495-503.

Benner, R., E. R. Peele \& R. E. Hodson, 1986. Microbial utilization of dissolved organic matter from leaves of the Red Mangrove, Rhizophora mangle, in the Fresh Creek Estuary, Bahamas. Estuarine, Coastal and Shelf Science 23: 607-619.

Bentzen, E., W. D. Taylor \& E. S. Millard, 1992. The importance of dissolved organic phosphorus to phosphorus uptake by limnetic plankton. Limnology and Oceanography 37: 217-231.

Boyer, J. N., 2005. FY2004 Annual Report of the South Florida Coastal Water Quality Monitoring Network. SERC Tech. Rep. T-265. http://www.serc.fiu.edu/wqmnetwork/ Report\%20Archive/2004CWQMN.pdf.

Boyer, J. N., J. W. Fourqurean \& R. D. Jones, 1997. Spatial characterization of water quality in Florida Bay and Whitewater Bay by multivariate analyses: zones of similar influence. Estuaries 20: 743-758.

Boyer, J. N., J. W. Fourqurean \& R. D. Jones, 1999. Seasonal and long-term trends in water quality of Florida Bay (19891997). Estuaries 22: 417-430.

Boyer, J. N. \& R. D. Jones, 1999. Effects of freshwater inputs and loading of phosphorus and nitrogen on the water quality of Eastern Florida Bay. In Reddy, K. R., G. A. O'Connor \& C. L. Schelske (eds), Phosphorus Biogeochemistry in Subtropical Ecosystems. CRC/Lewis Publishers, Boca Raton, FL, 545-561.

Boynton W. R., W. M. Kemp, C. W. Keefe, 1982. A comparative analysis of nutrients and other factors influencing estuarine phytoplankton production. In Kennedy, V. (ed.), Estuarine Comparisons. Academic Press, 69-90.

Brand, L., 1999. Nutrient bioassays and the Redfield ratio in Florida Bay. Abstracts of the 1999 Florida Bay and Adjacent Marine Systems Science Conference. Key Largo, FL, 78-79.

Bugden, J. B. C., M. A. Guerrero \& R. D. Jones, 1998. Spatial and temporal variation of marine bacterioplankton in Florida Bay, USA. Journal of Coastal Research 14: 1304-1313.

Carlsson, P. \& E. Graneli, 1993. Availability of humic bound nitrogen for coastal phytoplankton. Estuarine, Coastal and Shelf Science 36: 433-447.

Caron, D. A., 1994. Inorganic nutrients, bacteria, and the microbial loop. Microbial Ecology 28: 295-298.

Cembella, A. D., N. J. Antia \& P. J. Harrison, 1984. The utilization of inorganic and organic phosphorus compounds as nutrients by eukaryotic microalgae: a multidisciplinary perspective. Part 1. CRC Critical Reviews in Microbiology 10: 317-391.

Chrost, R. J., 1990. Microbial ectoenzymes in aquatic environments. In Overbeck, J. \& R. J. Chrost (eds), Aquatic Microbial Ecology: Biochemical and Molecular Approaches. Springer-Verlag, 47-78.

Coleman, A. W., 1980. Enhanced detection of bacteria in natural environments by flourochrome staining of DNA. Limnology and Oceanography 25: 948-951.
Cotner, J. B., R. H. Sada, H. Bootsma, T. Johengen, J. F. Cavaletto \& W. S. Gardner, 2000. Nutrient limitation of heterotrophic bacteria in Florida Bay. Estuaries 23: 611-620. del Giorgio, P. A. \& J. J. Cole, 1998. Bacterioplankton growth efficiency in aquatic systems. Annual Review of Ecological Systematics 29: 503-541.

del Giorgio, P. A. \& J. Davis, 2003. Patterns in dissolved organic matter lability and consumption across aquatic ecosystems. In Findlay, S. E. G. \& R. L. Sinsabaugh (eds), Aquatic Ecosystems: Interactivity of Dissolved Organic Matter. Academic Press, 399-424.

Ducklow, H. W. \& C. A. Carlson, 1992. Oceanic bacterial production. Advances in Microbial Ecology 12: 113-181.

Fourqurean, J. W., R. D. Jones \& J. C. Zieman, 1993. Processes influencing water column nutrient characteristics and phosphorus limitation of phytoplankton biomass in Florida Bay, FL, USA: inferences from spatial distributions. Estuarine, Coastal and Shelf Science 36: 295-314.

Frankovich, T. A. \& R. D. Jones, 1998. A rapid, precise, and sensitive method for the determination of total nitrogen in natural waters. Marine Chemistry 60: 227-234.

Garaudet, H., J. L. Berthon \& B. Buisson, 1997. Comparison of the daily alkaline phosphatase activity of a cyanobacterium (Microcystis aeruginosa) and a diatom (Synedra capitata). Comptes rendus de l'Académie des sciences. Série III, Sciences de la vie 320: 451-458.

Glibert, P. M., C. A. Heil, D. Hollander, M. Revilla, A. Hoare, J. Alexander \& S. Murasko, 2004. Evidence for dissolved organic nitrogen and phosphorus uptake during a cyanobacterial bloom in Florida Bay. Marine Ecology Progress Series 280: 73-83.

Hashimoto, S., K. Fujiwara \& K. Fuwa, 1985. Relationship between alkaline phosphatase activity and orthophosphate in the present Tokyo Bay. Journal of Environmental Science and Health, Part A 20A: 781-908.

Holmquist, J. G., G. V. N. Powell \& S. M. Sogard, 1989. Sediment, water level and water temperature characteristics of Florida Bay's grass-covered mud banks. Bulletin of Marine Science 44: 348-364.

Jaffe, R., J. N. Boyer, X. Lu, N. Maie, C. Yang \& N. Scully, 2003. Source characterization of dissolved organic matter in a subtropical mangrove-dominated estuary by fluorescence analysis. Marine Chemistry 84: 195-210.

Kitano, Y., M. Okumura \& M. Idogaki, 1978. Uptake of phosphate ions by calcium carbonate. Geochemistry Journal 12: 29-37.

Lavrentyev, P. J., H. A. Bootsma, T. H. Johengen, J. F. Cavaletto \& W. S. Gardner, 1998. Microbial plankton response to resource limitation: insights from the community structure and seston stoichiometry in Florida Bay, USA. Marine Ecology Progress Series 165: 45-57.

Lewitus, A. J., E. T. Koepfler \& R. J. Pigg, 2000. Use of dissolved organic nitrogen by a salt marsh phytoplankton bloom community. Limnology and Lake Management $2000+$. Proceedings of the Kinneret Symposium, Ginnosar, Israel, Sept. 1998. No. 55, pp. 15-29. Advances in limnology. Stuttgart. 
Maie, N., J. N. Boyer, C. Yang \& R. Jaffé, 2006. Spatial, geomorphological, and seasonal variability of CDOM in estuaries of the Florida Coastal Everglades. Hydrobiologia 569: $135-150$

Nausch, M. \& G. Nausch, 2004. Bacterial utilization of phosphorus pools after nitrogen and carbon amendment and its relation to alkaline phosphatase activity. Aquatic Microbial Ecology 37: 237-245.

Phlips, E. J. \& S. Badylak, 1996. Spatial variability in phytoplankton standing crop and composition in a shallow innershelf lagoon, Florida Bay, Florida. Bulletin of Marine Science 58: 203-216.

Phlips, E. J., S. Badylak \& T. C. Lynch, 1999. Blooms of the picoplanktonic cyanobacterium Synechococcus in Florida Bay, a subtropical inner-shelf lagoon. Limnology and Oceanography 44: 1166-1175.

Phlips, E. J., C. Zeman \& P. Hansen, 1989. Growth, photosynthesis, nitrogen fixation, and carbohydrate production by a unicellular cyanobacterium, Synechococcus sp. (Cyanophyta). Journal of Applied Phycology 1: 137-145.

Porter, K. G. \& Y. Feig, 1980. The use of DAPI for identifying and counting aquatic microflora. Limnology and Oceanography 25: 934.

Rudnick, D., Z. Chen, D. Childers, T. Fontaine \& J. N. Boyer, 1999. Phosphorus and nitrogen inputs to Florida Bay: the importance of the Everglades watershed. Estuaries 22: 398-416.

Sculley, N. M., N. Maie, S. K. Dailey, J. N. Boyer \& R. Jaffe, 2004. Photochemical and microbial transformation of plant derived dissolved organic matter in the Florida Everglades. Limnology and Oceanography 49: 1667-1678.
Smith, R. E. H. \& J. Kalff, 1981. The effect of phosphorus limitation on algal growth rates: evidence from alkaline phosphatase. Canadian Journal of Fisheries and Aquatic Sciences 38: 1421-1427.

Sobszak, W. V., J. E. Cloern, A. D. Jassby \& A. B. MullerSolger, 2002. Bioavailability of organic matter in a highly disturbed estuary: the role of algal and detrital resources. Proceedings of the National Academy of Science 99: 81018105.

Solorzano, L. \& J. H. Sharp, 1980. Determination of total dissolved phosphorus and particulate phosphorus in natural waters. Limnology and Oceanography 25: 754-758.

Steidinger, K. A., \& E. J. Phlips, 1996. Florida Bay microalgal blooms: composition, abundance, and distribution. Abstracts of the 1996 Florida Bay Science Conference. Florida Sea Grant, 77-79.

Stepanauskas, R., 2000. Utilization of terrestrially derived dissolved organic nitrogen. Dissertation. Lund University, Lund, Sweden.

Tezuka, Y., 1990. Bacterial regeneration of ammonium and phosphate as affected by the carbon:nitrogen:phosphorus ratio of organic substrates. Microbial Ecology 19: 227-238.

Turney, W. J. \& B. F. Perkins, 1972. Molluscan distribution in Florida Bay. Sedimenta III. RSMAS, University of Miami. $37 \mathrm{pp}$.

Waser, N. A. D., P. J. Harrison, B. Nielsen, S. E. Calvert \& D. H. Turpin, 1998. Nitrogen isotope fractionation during the uptake and assimilation of nitrate, nitrite, ammonium, and urea by a marine diatom. Limnology and Oceanography 43: 215-224. 